\title{
Influence of Comic Media Implementation in Islamic education Learning of Students in the School
}

\author{
Nuraini $^{1}$, Anip Dwi Saputro ${ }^{2}$ \\ Program Study of Islamic Education, FAI, Universitas Muhammadiyah Ponorogo, Indonesia ${ }^{1}$ \\ Program Study of Teacher Education Madrasah Ibtidaiyah, FAI, Universitas Muhammadiyah \\ Ponorogo, Indonesia ${ }^{2}$ \\ $\left\{\underline{\text { nuraini.imutt@gmail.com }}{ }^{1}, \underline{\text { anipdwisaputro@gmail.com }}{ }^{2}\right\}$
}

\begin{abstract}
Teachers consciously plan their teaching activities (learning process) systematically by utilizing everything for the sake of teaching because the learning process is the most important part of an educational activity. Comic media can be applied to convey messages in various sciences, and because of its attractive appearance. This media is very interesting in students' lives and is widely available in reading stores as well as the fact that some of the students recognize and memorize the characters of the comics they see.This research will be conducted on junior high school 6 Grade 7 or 8 students because at that time it is a transition period to adult,so it needs a media to improve learning achievement, quality,and efficiency of learning. This study aims to produce or develop a product and test it, namely improving the quality and efficiency of learning Islamic religious education through the use of comics as a medium of learning. The new product is Islamic education comic learning media. This research type is Quantitative Research that is by experimenting with using a comic learning media product in Islamic education splitting. Based on the results of the evaluation in which the learning objectives have been achieved, by looking at the results of the analysis with T-Test with Independent Samples hypothesis results stated that: There is the influence of learning using comic learning media Islamic education more effective and efficient than using conventional learning media.
\end{abstract}

Keywords: Media Comics, Learning, Islamic education.

\section{Introduction}

Learning is an educative activity. Educative values color interaction between teachers and learners. Interaction can be educative because the teaching and learning activities undertaken by teachers are directed to achieve certain goals that have been formulated before teaching is done, which is none other than to achieve educational goals[1].Teachers consciously plan their teaching activities (learning process) systematically by utilizing everything for the sake of teaching because the learning process is the most important part of an educational activity.

National Education functions to develop the ability and form the character and civilization of a dignified nation in order to educate the nation's life[2], aims to develop the potential of learners to become human beings who believe and pious to God Almighty, precious, healthy, 
knowledgeable, accomplished, creative, independent, and become citizens of a democratic and responsible (Undang - Undang Sisdiknas No. 20 Tahun 2005)[3].

The learning process, so that students are motivated in learning on the subject matter of Islamic Religious Education, especially in Kabupaten Ponorogo required a medium to facilitate the delivery of materials or messages[4]. By using the media, students will be more interested to learn because the material received more easily understood and students do not feel bored because the learning process is more varied. Learning media can be used to channel messages from the sender to the recipients to stimulate the thoughts, feelings, attention, and interests and attention of students so that the learning process occurs[5].

Comic media is one form of learning resources that can help students and can replace the position of teachers in learning activities both in class and outside the classroom. Comic media can be used in a two-way learning process, namely as a learning tool and as a medium of learning that can be used alone by students. From field observation that the learning of Islamic education in the form of learning comic has never been utilized. So that the presence of learning media in the form of comics is expected to help teachers or lecturers in the process of learning in the classroom to run in quality (effective) and efficient.

Ponorogo regency that has a background as a city of religious and santri city with the number of boarding schools that are available. Based on the situation and conditions whether the use of comic media in Islamic education learning whether it can take place effectively and efficiently[6].

Another factor is the selection of comic media because it is very interesting in students' lives and is widely available in reading stores as well as the fact that some of the students recognize and memorize the characters of the comics they see[7]. This research was conducted on the students in Ponorogo regency because at that time it was a transition to adulthood,so it needs a media to improve learning achievement, quality,and efficiency of learning Islamic education in Ponorogo regency.

Through the comic media used in group discussion activities can support improving the quality and efficiency of student learning, especially students who have difficulty in learning.

Based on the above, the researcher intends to arrange research with the title "Influence of Comic Media Implementation In Learning Islamic education Students in School." Based on the title then the purpose of this study are:

To know how much influence the use of comic media Islamic education compared with conventional learning media for students in School.

\section{Methods}

\subsection{Type of Research}

The type of this research is Quantitative research with Quasi Eksperimen this study aims to determine the effectiveness of the use of comic media in learning Islamic education. Quantitative research is a research process using data based on numbers and values. Products to be studied is a comic learning media Islamic education.

\subsection{Test Design Media Learning Learning Company Islamic education}

The experimental design in the class (Experiment) uses the Anakova (Analysis of Covariance)[8]. Can be seen in the following table: 
Image 1.Analysis Design of Covariance

Information :

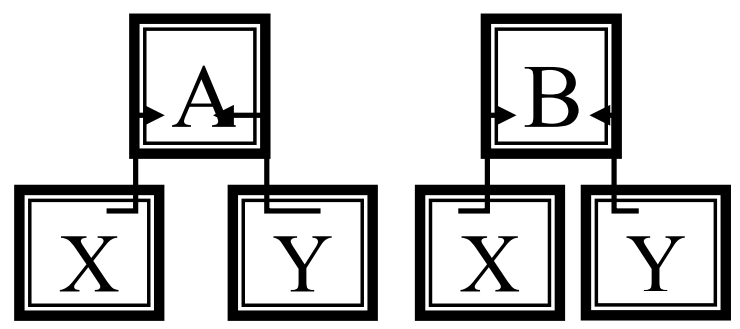

$\mathrm{X}=$ Quality of Learning.

$\mathrm{Y}=$ Efficiency of Learning.

$\mathrm{A}=$ Comic Learning Media of Islamic education.

$\mathrm{B}=$ Conventional Learning Media (Book of Islamic education).

This test is done to know the relation of quality and efficiency of student learning when using conventional learning media (control class) and comic media of Islamic education result of development (treatment class). Students 'learning outcomes are divided into two, namely the pretest-posttest score and the students' repetitiveness in answering the questions. Before the data analysis is done, Test-Anakova must first be tested requirements analysis. This step is to determine what kind of analysis technique should be used. The test is:

\subsubsection{Normality of Data Distribution}

Normality test is used to determine whether the data collected from each variable normal distributed or not. To know the normal distribution of data or not to test Kolmogorov-Smirnov one sample. As for the detailed calculations can be completed with the help of computer program SPSS 18.0.Datais normally distributed if Probability or $\mathrm{P}>0.05$ [9]. As for the normality test formula is as follows:

$$
D=\text { maximum } \mid F_{0}(X)-S_{n}(X)
$$

\subsubsection{Homogeneity Variant}

In addition to testing the spread of values analyzed in generalizing the results of the study must first be sure that the groups that make up the sample are from the same population[10]. Homogeneity test aims to determine whether the sample comes from a homogeneous population or not. Homogeneity test can be done by the variant test as follows:

\section{$F=$ Biggest Variant Smallest Variant}

Price F Calculate compared to the price of f-table with the numeric $\mathrm{db}(\mathrm{nb}-1)$ and the denominator ( $\mathrm{nk}-1$ ). Data is said to come from a homogeneous population if $\mathrm{F}$ arithmetic $<\mathrm{F}$ table or can also if $\mathrm{P}>0.05$ [9]. Homogeneity testing can be completed with the help of the computer program SPSS 18.0. 


\subsection{Trial Subjects}

The test subject in development here is the target or the user of the product that will be developed that is the junior high school class VII. A trial conducted at SMP N 6 Ponorogo. In addition to facilitating research, the reason for choosing SMP N 6 Ponorogo. To place the test is based on preliminary research that in this school special class VII SMP requires the need for variations in learning Islamic education, thereby can overcome the students so as not to saturate and bored in the process of learning Islamic education and will facilitate teachers in the delivery of material in the form of print media namely the comic media learning Islamic education as an introduction to discussion and has never been applied in the junior high school. From the school and teachers in the field of study, Islamic education states that the print media that is learning comic media learning Islamic education here needs to be tested first so that further can be utilized in the actual learning process Islamic education in the school.

\subsection{Data Collect Instruments}

\subsubsection{Pre-Observation}

Before conducting observation first pre-observation by visiting the school to be observed, then contact the classroom teachers who teach at the school, then observed the circumstances surrounding the class, the number of students who will eventually support the implementation of observations of the next stage of pre-observation.

\subsubsection{Observation}

Observation was carried out during preliminary research and collected information on learning tools it Islamic education Comics Media to be used and developed.

\subsubsection{Interview}

Interviews were conducted during preliminary research and collection of information on the Islamic education comic media.

\subsection{Techniques of Data Analysis}

Data Collected data is analyzed through one statistical test. Quantitative data in the form of calculated or measurement figures can be processedbyusingT-Test analysis [11]; with Independent Samples using SPSS 18 Software.

\section{Results and discussion}

\subsection{Analysis of Product Experimental Results In Class Control and Treatment.}

\subsubsection{Normality test}

The normality test aims to test whether the data obtained is normally distributed or not and to test the significance of the difference (o and (h-) This test uses the Kolmogorov-Smirnov formula:

The result of control class normality test shows p-value (.sig) $=0,056>\alpha=0,05$. The minimum difference in pre-test value is 0 and maximum of 14.4 . 
Ho: Normal distribution

Ha: Not normally distributed

The value of $p$-value $(. \operatorname{sig})=0.056>\alpha=0.05$ then Ho accepted means normal distribution; the complete result of the control class normality test can be seen as follows:

Table 1. Tests of Normality

\begin{tabular}{ccccccc} 
& \multicolumn{3}{c}{ Kolmogorov-Smirnov } & \multicolumn{3}{c}{ Shapiro-Wilk } \\
& Statistic & Df & Sig. & Statistic & df & Sig. \\
Kelas Kontrol & .144 & 20 & .056 & .960 & 20 & .208
\end{tabular}

a. Lilliefors Significance Correction

The result of normality class test showed $p$ value $(. \mathrm{sig})=0,200>\alpha=0,05$. The minimum difference in pre-test value is 44 and a maximum of 68 .

Ho: Normal distribution

Ha: Not normally distributed

The value of $p$-value (.sig) $=0,200>\alpha=0.05$ then Ho accepted means normal distribution, the complete result of the control class normality test can be seen as follows:

Table 2. Tests of Normality

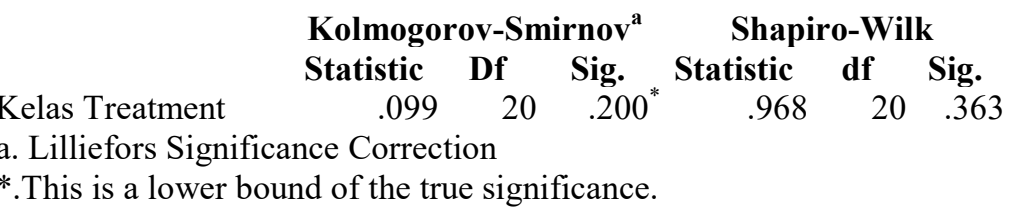

\subsubsection{Homogeneity Test}

Homogeneity test of variance aims to determine whether samples taken from the population have different variants of each other (samples are homogeneous or not). The investigated population is said to be homogeneous if the value of $p$-value is greater than 0.05 at a significant level of $5 \%$.

From result of homogeneity test of control class with treatment class obtained result $\mathrm{p}$ value $(. \operatorname{sig})=0339<\alpha=0,05$ then Ho accepted mean homogeneous data. For t-test calculation, then it can be done because it meets the prerequisite test. The complete results of the homogeneity test can be seen as follow :

Table 3. Test of Homogeneity of Variance

\begin{tabular}{cccccc}
\hline & Levene Statistic & df1 & df2 & Sig. \\
\hline Nilai & Based on Mean & .928 & 1 & 70 & .339 \\
\cline { 2 - 6 } & Based on Median & .884 & 1 & 70 & .350 \\
\cline { 2 - 6 } & $\begin{array}{c}\text { Based on Median and with } \\
\text { adjusted df }\end{array}$ & .884 & 1 & 68.314 & .351 \\
\cline { 2 - 6 } & Based on trimmed mean & .921 & 1 & 70 & .341 \\
\hline
\end{tabular}




\subsubsection{Islamic education Comic Learning Media in Improving Student Learning Achievement}

This research was conducted in Grade VII of SMPN 6 Ponorogo in 2 class which become sample, that is class VII-A as control class by using conventional media commonly used by teachers in the school to teach, and class VII-F as treatment class with media Islamic education comics that have been adapted to the learning materials. Based on the research objectives to be achieved in this research, namely to know the extent of the influence of the relationship between learning media, pretest score as covariance and the value of student achievement in learning Islamic education class VII in SMPN 6 Ponorogo conducted in 2 classes. The data were obtained by research instrument which is a question (pre and post-test) for use in T-test for Independent Samples.

To Determine the Influence of Effect of Media Usage on Learning Outcomes, data collection of learning achievement was done on learning with pre-test and post test which was conducted in treatment class by using comic media and control class with book media used by the school which then taken Hypothesis Test Analysis ,performed by T-test for Independent Samples to find out how much influence the use of comic learning media Islamic education compared with the use of conventional learning media for students in the School.

If the data of the research results meet the requirements of Normality and Homogeneity Test, then hypothesis testing can be done. Hypothesis Test Analysis, conducted by T-Test for Independent Samples to find out how much influence the use of comic learning media Islamic education compared with the use of conventional learning media. T-Test Test results are more fully viewed in the following;

Tabel 4. Group Statistics

\begin{tabular}{|c|c|c|c|c|c|}
\hline & Perlakuan & $\mathbf{N}$ & Mean & $\begin{array}{c}\text { Std. } \\
\text { Deviation }\end{array}$ & $\begin{array}{l}\text { Std. Error } \\
\text { Mean }\end{array}$ \\
\hline \multirow{2}{*}{$\begin{array}{l}\text { Nilai } \\
\text { Postest }\end{array}$} & Media Komik & 20 & 84.75 & 9.101 & 2.035 \\
\hline & $\begin{array}{l}\text { Media } \\
\text { Konvensional }\end{array}$ & 20 & 73.75 & 6.043 & 1.351 \\
\hline
\end{tabular}

Tabel 5. Independent Samples Test

\begin{tabular}{|c|c|c|c|c|c|c|c|c|c|c|}
\hline & & $\begin{array}{r}\text { Leve } \\
\text { Test } \\
\text { Equal } \\
\text { Varia }\end{array}$ & $\begin{array}{l}\text { ne's } \\
\text { for } \\
\text { ity of } \\
\text { inces }\end{array}$ & & & t-test fo & or Equality & of Means & & \\
\hline & & \multirow[b]{2}{*}{$\mathbf{F}$} & \multirow[b]{2}{*}{ Sig. } & \multirow[b]{2}{*}{$\mathbf{T}$} & \multirow[b]{2}{*}{ df } & \multirow{2}{*}{$\begin{array}{l}\text { Sig. (2- } \\
\text { tailed) }\end{array}$} & \multirow{2}{*}{$\begin{array}{c}\text { Mean } \\
\text { Difference }\end{array}$} & \multirow{2}{*}{$\begin{array}{l}\text { Std. } \\
\text { Error } \\
\text { Differe } \\
\text { nce }\end{array}$} & \multicolumn{2}{|c|}{$\begin{array}{c}95 \% \\
\text { Confidence } \\
\text { Interval of the } \\
\text { Difference } \\
\end{array}$} \\
\hline & & & & & & & & & Lower & Upper \\
\hline $\begin{array}{l}\text { Nilai } \\
\text { Postes }\end{array}$ & $\begin{array}{c}\text { Equal } \\
\text { variances } \\
\text { assumed }\end{array}$ & 5.561 & .024 & 4.503 & 38 & .000 & 11.000 & 2.443 & 6.055 & 15.945 \\
\hline
\end{tabular}


Tabel 5. Independent Samples Test

\begin{tabular}{|c|c|c|c|c|c|c|c|c|c|c|}
\hline & & $\begin{array}{l}\text { Lev } \\
\text { Tes } \\
\text { Equa } \\
\text { Vari }\end{array}$ & $\begin{array}{l}\text { ne's } \\
\text { for } \\
\text { ity of } \\
\text { nces }\end{array}$ & & & t-test fo & or Equality & of Means & & \\
\hline & & \multirow[b]{2}{*}{$\mathbf{F}$} & \multirow[b]{2}{*}{ Sig. } & \multirow[b]{2}{*}{$\mathbf{T}$} & \multirow[b]{2}{*}{ df } & \multirow{2}{*}{$\begin{array}{l}\text { Sig. (2- } \\
\text { tailed) }\end{array}$} & \multirow{2}{*}{$\begin{array}{c}\text { Mean } \\
\text { Difference }\end{array}$} & \multirow{2}{*}{$\begin{array}{l}\text { Std. } \\
\text { Error } \\
\text { Differe } \\
\text { nce }\end{array}$} & \multicolumn{2}{|c|}{$\begin{array}{c}95 \% \\
\text { Confidence } \\
\text { Interval of the } \\
\text { Difference }\end{array}$} \\
\hline & & & & & & & & & Lower & Upper \\
\hline \multirow[t]{2}{*}{$\begin{array}{l}\text { Nilai } \\
\text { Postes }\end{array}$} & $\begin{array}{c}\text { Equal } \\
\text { variances } \\
\text { assumed }\end{array}$ & 5.561 & .024 & 4.503 & 38 & .000 & 11.000 & 2.443 & 6.055 & 15.945 \\
\hline & $\begin{array}{c}\text { Equal } \\
\text { variances } \\
\text { not } \\
\text { assumed }\end{array}$ & & & 4.503 & 33.026 & .000 & 11.000 & 2.443 & 6.030 & 15.970 \\
\hline
\end{tabular}
Hypothesis

The criteria for determining and rejecting the hypothesis are as follows:

- $\mathrm{H} 0: \mathrm{m} 1=\mathrm{m} 2$ (There is no effect of learning using comic media compared to conventional media)

- $\mathrm{H} 1: \mathrm{m} 1 \neq \mathrm{m} 2$ (there is the influence of learning using comic media compared to conventional media)

- $\alpha=0.05$

- Critical area.

- $\quad \mathrm{H} 0$ is rejected if $\mathrm{p}$ value (Sig. (2-Tailed)) $<0.05$.

- Test Statistics.

- $\quad$ P value (Sig. (2. Tailed)) $=0.000$.

- Conclusion

Because p-value (Sig. (2. Tailed)) $<0.05$ then $\mathrm{H} 0$ is rejected so it can be concluded that there is a difference of learning effect using Islamic education comic media compared with conventional media usage.

Student interest in learning resources is a very good symptom to improve student achievement. As a teacher, creating student interest in instructional learning is a must, so that students are motivated to learn.

A teacher's creativity is tested, how to present interesting and fun teaching materials for students, to improve their learning outcomes. Islamic education comic media here serves as an introduction to the discussion in groups that have been divided into classes[12]. So through the Islamic education comic media is influential in group discussions to be more efficient, effective, critical and creative. Islamic education comic learning media makes students able to understand and remembering subject matter well discussed so that student learning achievement also increases. 


\section{Conclusion}

Islamic education comic learning media is designed for group learning and serves as an introduction to the discussion, because this learning using STAD type learning approach, then the teacher should be a facilitator and should accompany the students in group discussions and not enough just released the students themselves. Teachers can provide explanations to help accelerate students' understanding and to discuss with students. Then this product can be used as a tool of the teacher in the learning process, which can improve student achievement in terms of cognitive aspect and critical thinking ability of the student.

Based on the results of the evaluation in which the learning objectives have been achieved, by looking at the results of the analysis with T-Test with Independent Samples whose hypothesis states that:

There is an influence of learning using Islamic education comic learning media more effectively and efficiently than using conventional learning media.

Based on the above analysis it can be concluded that: " Islamic education comic learning media can improve learning achievement and more effective and efficient compared with conventional learning media."

\section{References}

[1] A. Ikhwan, "Integrasi Pendidikan Islami (Nilai-Nilai Islami dalam Pembelajaran)," Ta'allum J. Pendidik. Islam, vol. 2, no. 2, p. 184, 2014.

[2] A. Ikhwan, "The Meanings of Teachers Professions in Islamic Educational Management," in IACiem (International Annual Conference on Islamic Educational Management), 2012.

[3] M. Suriadi Samsuri, Mursidin, "Character Education Based on Gender Justice in The Islamic Perspective," Al-Hayat J. Islam. Educ., vol. 2, no. 2, pp. 202-212, 2018.

[4] A. Ikhwan, Filsafat Pendidikan Islam: Memahami Prinsip Dasar. Yogyakarta: Diandra Kreatif, 2018.

[5] M. S. Kahar and D. Pabalik, "Profil Pendidikan Karakter Mahasiswa Non Muslim dalam Implementasi Al-Islam dan Kemuhammadiyahan," Al-Hayat J. Islam. Educ., vol. 2, no. 1, pp. 79-88, 2018.

[6] N. A. Sri Wahyuni, Nuraini Nuraini, "Strategi Pendidikan Unggul Berbasis Organisasi di Pimpinan Daerah Ikatan Pelajar Muhammadiyah Ponorogo," Istawa J. Pendidik. Islam, vol. 3, no. 2, pp. 97-110, 2018.

[7] A. Ikhwan, Pengembangan Kurikulum Pendidikan Agama Islam (PAI). Malang: Insan Cita Press dan STAIM Tulungagung, 2013.

[8] M. D. Gall, W. R. Borg, and J. P. Gall, Educational research: An introduction. New York: Longman, 1983.

[9] Sugiyono, Metode Penelitian Pendidikan Pendekatan Kuantitatif, Kualitatif dan $R$ \& D. Bandung: Alfabeta, 2009.

[10] S. Arikunto, Prosedur Penelitian, Suatu Praktek. Jakarta: Bina Aksara, 2003.

[11] S. Arikunto, Prosedur Penelitian Suatu Penelitian Praktek. Jakarta: Rineka Cipta, 1998.

[12] A. Ikhwan, "MANAGEMENT OF LEARNING ASSESSMENT USING CURRICULUM 2013 (CASE STUDY IN ISLAMIC PRIMARY SCHOOL (MI) MUHAMMADIYAH 5 WONOASRI PONOROGO - EAST JAVA - INDONESIA)," 
MUADDIB Stud. Kependidikan dan Keislam., vol. 08, no. 02, pp. 108-123, 2018. 